\title{
Nanocomposite polymer electrolyte for rechargeable magnesium batteries
}

Yuyan Shao, ${ }^{*}{ }^{\dagger}$ Nav Nidhi Rajput, ${ }^{\ddagger}$ Jianzhi Hu, ${ }^{\dagger}$ Mary Hu, ${ }^{\dagger}$ Tianbiao Liu, ${ }^{\dagger}$ Zhehao Wei, ${ }^{\dagger,}{ }^{\#}$ Meng Gu, ${ }^{\dagger}$ Xuchu Deng, ${ }^{\dagger}$ Suochang Xu, Kee Sung Han, ${ }^{\dagger}$ Jiulin Wang,${ }^{\dagger}$ Zimin Nie,${ }^{\dagger}$ Guosheng Li, ${ }^{\dagger}$ Kevin R. Zavadil, ${ }^{\mathbb{I}}$ Jie Xiao, ${ }^{\dagger}$ Chongmin Wang, ${ }^{\dagger}$ Wesley A. Henderson, ${ }^{\dagger}$ Ji-Guang Zhang, ${ }^{\dagger}$ Yong Wang, ${ }^{\dagger,}, \#$ Karl T. Mueller, ${ }^{\dagger, \pm}$ Kristin Persson, ${ }^{*, \grave{ }}$ Jun Liu ${ }^{*, \dagger}$

${ }^{\dagger}$ Pacific Northwest National Laboratory, Richland, WA 99352, USA

${ }^{\ddagger}$ Lawrence Berkeley National Laboratory, Berkeley, CA 94720, USA

\# The Gene and Linda Voiland School of Chemical Engineering and Bioengineering, Washington State University, Pullman, WA 99164, USA

"I Sandia National Laboratories, Albuquerque, NM 87185, USA

${ }^{ \pm}$Department of Chemistry, Pennsylvania State University, University Park, PA 16802, USA

*Corresponding authors.

Email addresses: jun.liu@pnnl.gov (J. Liu), kapersson@1bl.gov (K. Persson)

\begin{abstract}
Nanocomposite polymer electrolytes present new opportunities for rechargeable magnesium batteries. However, few polymer electrolytes have demonstrated reversible $\mathrm{Mg}$ deposition/dissolution and those that have still contain volatile liquids such as tetrahydrofuran (THF). In this work, we report a nanocomposite polymer electrolyte based on poly(ethylene
\end{abstract}


oxide) (PEO), $\mathrm{Mg}\left(\mathrm{BH}_{4}\right)_{2}$ and $\mathrm{MgO}$ nanoparticles for rechargeable $\mathrm{Mg}$ batteries. Cells with this electrolyte have a high coulombic efficiency of $98 \%$ for $\mathrm{Mg}$ plating/stripping and a high cycling stability. Through combined experiment-modeling investigations, a correlation between improved solvation of the salt and solvent chain length, chelation and oxygen denticity is established. Following the same trend, the nanocomposite polymer electrolyte is inferred to enhance the dissociation of the salt $\mathrm{Mg}\left(\mathrm{BH}_{4}\right)_{2}$ and thus improve the electrochemical performance. The insights and design metrics thus obtained may be used in nanocomposite electrolytes for other multivalent systems.

Keywords: Energy storage; Battery; Nanocomposite; Polymer electrolyte; Magnesium; Rechargeable

\section{Introduction}

Magnesium batteries have attracted increasing attention as a potentially low-cost, safe technology for large scale applications such as transportation and grid storage $[1,2]$. Magnesium—a divalent charge carrier-exhibits several intrinsic advantages for battery applications over other metals such as $\mathrm{Li}$ or $\mathrm{Na}$. Mg metal is much less reactive in air than both $\mathrm{Li}$ and $\mathrm{Na}$ which makes it safer to handle; it has a significantly higher volumetric capacity (i.e., $3832 \mathrm{mAh} \mathrm{cm}^{-3} \mathrm{Mg}, 2062 \mathrm{mAh} \mathrm{cm}^{-3} \mathrm{Li}_{\text {in }} 1136 \mathrm{mAh} \mathrm{cm}_{\mathrm{Na}}^{-3}$ ); and smooth, dendrite-free $\mathrm{Mg}$ deposition [3,4] and close to a 100\% coulombic efficiency (CE) for plating/stripping [5] have been demonstrated in selected electrolytes. These findings are potentially transformative since dendrite formation and low CE have been historic obstacles for Li metal battery development [68]. Finally, $\mathrm{Mg}$ is both abundant and inexpensive. 
Over the past few years, extensive progress has been made in the rechargeable Mg battery field, especially with regard to electrolyte design and development [5, 9-22]. Magnesium forms a 'truly' passivating film in contact with oxygen or conventional electrolytes (i.e., mixtures of simple $\mathrm{Mg}$ salts and aprotic solvents, analogous to those in Li-ion batteries [23]), which impedes $\mathrm{Mg}^{2+}$ transfer [24-26]. Hence, a rechargeable Mg battery requires electrolytes in which no "solid electrolyte interphase" (SEI) or a weakened passivation layer is formed on the Mg metal surface to enable highly reversible $\mathrm{Mg}$ plating/stripping [2, 21, 27-31]. This design metric is in contrast to $\mathrm{Li}$-ion batteries in which a stable, but $\mathrm{Li}^{+}$conductive $\mathrm{SEI}$ is formed [32]. To date, functional electrolytes for a rechargeable $\mathrm{Mg}$ battery consist of complicated Mg complexes which possess a partial organometallic character $[2,5,11,13,21,33]$. These electrolytes usually also contain volatile solvents such as THF [2, 21, 34-36], which present a safety concern. The search for Mg electrolytes with solvents exhibiting higher boiling points, including ionic liquids [37, 38], has been performed [39-41]. However, even though electrochemical Mg plating/stripping behavior has been reported in systems using ILs [42, 43] and glymes [41], the reproducibility and truly reversible Mg plating/stripping in these systems still need to be confirmed [28, 35], as large overpotentials and low CEs are observed [41, 44-46].

Solid-state batteries (mostly based upon $\mathrm{Li}$ or $\mathrm{Na}$ chemistries [47-49]) provide great advantages such as flexibility in dimensions/geometry, ease of fabrication, a potentially high energy density, and most importantly high safety $[49,50]$. Solid-state electrolytes for battery applications can be roughly classified into two categories: inorganic and polymer-based. Recently, it has been reported [40] that a $\mathrm{Mg}\left(\mathrm{BH}_{4}\right)\left(\mathrm{NH}_{2}\right)$ solid-state electrolyte can enable reversible Mg plating/stripping (but with a CE of less than $50 \%$ and conductivity of $10^{-6} \mathrm{~S} / \mathrm{cm}$ at 
$150^{\circ} \mathrm{C}$ ). There is also a recent report using metal-organic frameworks as a solid Mg electrolyte, but no electrochemical data have been demonstrated [51].

Significant efforts have been devoted to polymer-based (such as poly(ethylene oxide), PEO) solid-state rechargeable $\mathrm{Mg}$ batteries [50,52-57]. However, most of the polymeric solid-state $\mathrm{Mg}$ electrolytes in the literature are based on simple $\mathrm{Mg}$ salts such as magnesium triflate $\mathrm{Mg}\left(\mathrm{SO}_{3} \mathrm{CF}_{3}\right)_{2}$ [58] and magnesium(II) bis(trifluoromethanesulfonyl)imide $\mathrm{Mg}\left(\mathrm{N}\left(\mathrm{SO}_{2} \mathrm{CF}_{3}\right)_{2}\right)_{2}$ (or $\left.\operatorname{Mg}(\mathrm{TFSI})_{2}\right)$ [59], similar to those for solid-state lithium electrolytes [60]. These salts are known to be incompatible with the $\mathrm{Mg}$ metal anode (i.e., unable to produce reversible $\mathrm{Mg}$ plating/stripping) [30, 35]; furthermore, it has been reported that the electrolytes based upon polymers and simple $\mathrm{Mg}$ salts are principally anion conductors (the transport number of $\mathrm{Mg}^{2+}$ being very low if not zero) because of the double charge and small size of $\mathrm{Mg}^{2+}$ [61-63]. There have been some efforts to increase the $\mathrm{Mg}^{2+}$ transference number, but no electrochemical properties—especially those pertaining to reversible Mg plating/stripping—have been reported $[64,65]$. Finally, there is one interesting report on solid-state Mg polymer electrolytes, consisting of PEO or PVDF and organometallic $\mathrm{Mg}$ complex salts, such as $\mathrm{Mg}(\mathrm{AlEtBuCl})_{2} / \mathrm{THF}$ or tetraglyme, by Aurbach and coworkers [50] demonstrating reversible Mg plating/striping.

To the best of our knowledge, there has been no report yet on Mg polymer electrolytes without flammable plasticizers that enable reversible Mg plating/stripping. More significantly, there is little fundamental understanding available on solid-state electrolytes for rechargeable $\mathrm{Mg}$ batteries. In this work, we report a new nanocomposite electrolyte based on PEO-Mg( $\left(\mathrm{BH}_{4}\right)_{2}$ for reversible $\mathrm{Mg}$ plating/stripping with a high $\mathrm{CE}$ and stable cycling. A design metric leading to this electrolyte chemistry has been elucidated using combined nuclear magnetic resonance (NMR) spectroscopy and theoretical molecular dynamics (MD) simulations. 


\section{Materials and methods}

\section{Chemicals}

Magnesium borohydride $\left(\mathrm{Mg}\left(\mathrm{BH}_{4}\right)_{2}, 95 \%\right)$, magnesium ribbon (99.5\%), $\mathrm{MgO}$ nanoparticles, polyethylene oxide (PEO, MW 600,000), and anhydrous tetrahydrofuran (THF) were purchased from Sigma-Aldrich. Magnesium bis(trifluoromethylsulfonyl)imide $\left(\mathrm{Mg}(\mathrm{TFSI})_{2}\right)$ was purchased from SOLVIONIC (France). Battery grade dimethoxyethane (DME), diglyme, triglyme, tetraglyme were obtained from Novolyte Technologies, Inc. The solvents were further dried over $3 \AA$ molecular sieve, PEO was dried under vacuum at $60^{\circ} \mathrm{C}$ for $24 \mathrm{~h}$, and $\mathrm{MgO}$ nanoparticles were dried under vacuum at $300{ }^{\circ} \mathrm{C}$ for $24 \mathrm{~h}$ before use.

\section{Nanocomposite polymer electrolyte preparation}

The nanocomposite $\mathrm{Mg}$ polymer electrolyte was prepared using literature methods as used for constructing solid-state lithium battery electrolytes: hot-press [66] or solution casting [67] methods. In brief, for the hot-press method, $\mathrm{PEO}, \mathrm{Mg}\left(\mathrm{BH}_{4}\right)_{2}$, and $\mathrm{MgO}$ nanoparticles with a specified composition were sealed in an airtight plastic bottle and mixed by ball-milling for at least $24 \mathrm{~h}$ to obtain a homogeneous mixture of the powders. The mass ratio of $\mathrm{Mg}\left(\mathrm{BH}_{4}\right)_{2} /$ $\mathrm{MgO} / \mathrm{PEO}$ is $1: 1: 8$ which corresponds to the ratio $\mathrm{Mg} / \mathrm{EO}=1: 10$ (the ratio is 1:20 for the $\left.\mathrm{Mg}(\mathrm{TFSI})_{2} / \mathrm{PEO}\right)$. The mixture was then hot-pressed in a specially designed die at a temperature ranging from 80 to $120^{\circ} \mathrm{C}$ for 10 to $30 \mathrm{~min}$. After cooling, it forms a semi-transparent thin film (Figure 1a-inset) which was then stored in an argon-filled glovebox. All processing was conducted without exposure to air. $\mathrm{MgO}$ nanoparticles were added to improve the conductivity and mechanical stability of the solid-state electrolytes $[49,68]$. For the solution casting method, in a typical procedure, a mixture containing appropriate amount of $\mathrm{PEO}, \mathrm{Mg}\left(\mathrm{BH}_{4}\right)_{2}$, and $\mathrm{MgO}$ 
was dissolved in THF and the resulting solution was poured into a Teflon dish. A free-standing electrolyte film was formed when the THF was slowly evaporated at room temperature. Again, all processing is conducted without exposure to air.

\section{Electrochemistry and cell test}

Cyclic voltammetry measurements using a CHI660 workstation were conducted in a standard three-electrode cell with a $\mathrm{Mg}$ metal ribbon used as the reference/counter electrodes. The working electrodes were Pt wire, glass carbon, or stainless steel 316. The electrolytes were prepared by dissolving $\mathrm{Mg}\left(\mathrm{BH}_{4}\right)_{2}$ in glyme solvents. All the electrochemical tests were conducted in an argon-filled glovebox. The $\mathrm{CE}$ was calculated by dividing the charge of $\mathrm{Mg}$ obtained during stripping over the charge for $\mathrm{Mg}$ plating. The solid-state $\mathrm{Mg}$ cells were assembled using commercial coin cell parts (standard 2030 parts from NRC Canada) and tested using an Arbin Battery Tester, a CHI660 workstation (for CV test) and a Solartron electrochemical test setup (Model 1287A Potentiostat/Galvanostat plus Model 1260A Impedance/Gain-phase Analyzer).

\section{Characterization}

All of the NMR experiments were carried out on a Varian-Agilent $900 \mathrm{MHz}$ NMR spectrometer at a magnetic field of $21.1 \mathrm{~T}$. The ${ }^{25} \mathrm{Mg} \mathrm{NMR}$ spectra were referenced to $1.0 \mathrm{M} \mathrm{MgCl}_{2}(0 \mathrm{ppm})$, while ${ }^{11} \mathrm{~B}$ MAS NMR spectra were referenced to neat $\mathrm{F}_{3} \mathrm{~B} \bullet \mathrm{O}\left(\mathrm{CH}_{2} \mathrm{CH}_{3}\right)_{2} \quad(0 \mathrm{ppm})$ using $0.1 \mathrm{M}$ $\mathrm{B}(\mathrm{OH})_{3}$ in $\mathrm{D}_{2} \mathrm{O}$ as a secondary reference at $19.6 \mathrm{ppm} .{ }^{1} \mathrm{H}$ NMR was referenced to TMS (0 ppm). The transmittance FTIR experiment was carried out on a Bruker IFS 66/S instrument with a mercury-cadmium-telluride (MCT) detector. X-Ray diffraction (XRD) patterns were obtained using a Philips Xpert X-ray diffractometer with $\mathrm{Cu} \mathrm{K \alpha}$ radiation at $\lambda=1.54 \AA$. Samples were sealed in a special XRD sample holder which prevents oxygen and moisture from contacting the 
samples. Scanning electron microscope (SEM) images were collected on a JEOL 5900 scanning electron microscope equipped with an EDAX energy dispersive $\mathrm{x}$-ray spectroscopy (EDS) system.

\section{Density functional theory (DFT) calculations}

Computational modeling was carried out using the Amsterdam Density Functional (ADF-2013) package. The generalized gradient approximation (GGA) based Becke-Lee-Yang-Parr function $[69,70]$ with dispersion correction (BLYP-D) [71] is employed for geometry optimization. All of the calculations were carried out using the TZ2P basis set (triple $Z, 2$ polarization functions, all-electron) with the Slater type functional [72] implemented in the ADF program. NMR calculation was performed based on the geometry optimized structures at the same level of the theory and with the same basis set to evaluate the chemical shielding tensors for each atom. For

${ }^{25} \mathrm{Mg}$, the chemical shift was referenced with respect to an $\mathrm{H}_{2} \mathrm{O}$ solvated magnesium ion (i.e., $\mathrm{Mg}$

${ }^{2+} \cdot 6 \mathrm{H}_{2} \mathrm{O}$ at $\left.0 \mathrm{ppm}\right)$. The calculated absolute isotropic chemical shift of $\mathrm{Mg}^{2+} \cdot 6 \mathrm{H}_{2} \mathrm{O}$ is $-565 \mathrm{ppm}$. The calculated absolute isotropic chemical shift is converted to the observed ppm with reference to $\mathrm{Mg}^{2+} \cdot 6 \mathrm{H}_{2} \mathrm{O}$ according to $\delta_{\text {iso }}(\mathrm{obs})=\delta_{\text {iso }}(\mathrm{cal})-(-565)=\delta_{\text {iso }}(\mathrm{cal})+565 \mathrm{ppm}$.

\section{Molecular dynamics simulations}

We performed classical molecular dynamics (MD) simulations using GROMACS MD simulation package version 4.5.3 [73]. The initial configurations were obtained by packing the molecules into a cubic box using PACKMOL [74]. The simulation box was made periodic in the xyz directions. The simulations were first performed in an isothermal-isobaric (constant NPT) ensemble for $2 \mathrm{~ns}$ to get the right density and then the production runs of $10 \mathrm{~ns}$ were obtained from a canonical (constant $N V T$ ) ensemble. The systems were energy minimized using the steepest descent followed by conjugated-gradient energy minimization schemes to relax the 
strained contacts between the ions and molecules in the initial configurations. A Berendsen barostat with time constant 2 ps was used to maintain the pressure of 1 bar and a velocity rescaling thermostat was used to control the temperature at $298 \mathrm{~K}$ with a time constant of $0.1 \mathrm{ps}$. A Verlet leapfrog integration algorithm was used with a time step of 1 fs. The long-range electrostatic interactions were truncated using the particle-mesh Ewald (PME) method at a cutoff distance of $1.2 \mathrm{~nm}$ and the Lennard-Jones interactions were truncated at $1.0 \mathrm{~nm}$. We used non-polarizable force fields for all the ions and molecules. The force field parameters for $\mathrm{Mg}^{2+}$ is taken from the OPLSAA force field developed by Jorgensen [75]. The force fields for $\mathrm{BH}_{4}{ }^{-}$and glymes were developed by using a combination of electronic structure calculations and parameters from generalized Amber force fields (GAFF) [76]. Bulk simulations at $0.01 \mathrm{M}$ contain $6 \mathrm{Mg}^{2+}$ and $12 \mathrm{BH}_{4}^{-}$with $5799 \mathrm{DME}, 3854$ diglyme, 3330 triglyme or 2773 tetraglyme, respectively, for the different glymes. The simulation box lengths were approximately $10 \mathrm{~nm}$.

\section{Results}

\section{SEM characterization}

The nanocomposite polymer electrolyte consists of PEO (MW 600,000), $\mathrm{Mg}\left(\mathrm{BH}_{4}\right)_{2}$ and $\mathrm{MgO}$ nanoparticles. From the SEM images of the nanocomposite, the surface was smooth (Figure 1a) and the $\mathrm{MgO}$ nanoparticles were uniformly dispersed in PEO (Figure 1b). From the cross-section images, the thickness of the film is estimated to be $200 \mu \mathrm{m}$ (Figure 1c) — the thickness is tunable through the amount of materials; and a dense and uniform structure is revealed in the SEM images (Figures 1c and 6d). The element mapping (Figures 1e and 6h), showing uniformity for the $\mathrm{Mg}, \mathrm{B}, \mathrm{C}$ and $\mathrm{O}$ elements, indicates that the salt $\mathrm{Mg}\left(\mathrm{BH}_{4}\right)_{2}$ and nanoparticles $\mathrm{MgO}$ are uniformly dispersed in PEO, consistent with the SEM images. 


\section{Electrochemical properties}

Figure 2 shows the electrochemical performance of the $\mathrm{Mg}$ cell at $100{ }^{\circ} \mathrm{C}$ with the nanocomposite electrolyte $\mathrm{Mg}\left(\mathrm{BH}_{4}\right)_{2}-\mathrm{MgO}-\mathrm{PEO}$. A reversible $\mathrm{Mg}$ plating/stripping is achieved and the $\mathrm{CE}$ is calculated to be $98 \%$ via dividing the electric charge for $\mathrm{Mg}$ stripping by the electric charge for $\mathrm{Mg}$ plating. A polymer electrolyte enabled reversible $\mathrm{Mg}$ plating/stripping with high efficiency is a key feature for solid-state rechargeable Mg batteries. The voltage gap between the onset potential for $\mathrm{Mg}$ plating and $\mathrm{Mg}$ stripping is only $0.2 \mathrm{~V}$ (note that this was in a two-electrode cell with $\mathrm{Mg}$ used as both the reference and counter electrodes), indicating high reversibility and fast kinetics. The current density is higher than for other polymer electrolytes [50] and solid-state electrolytes [40] reported in the literature. Reversible Mg intercalation/deintercalation in the cathode $\mathrm{Mo}_{6} \mathrm{~S}_{8}$ is also shown in Figure 2b. The charge/discharge curves (Figure 2c) show very flat plateaus and the cell using the nanocomposite electrolyte exhibits very high cycling stability for at least 150 cycles (Figure $2 \mathrm{~d}$ ). The Chevrel phase $\mathrm{Mo}_{6} \mathrm{~S}_{8}$ is selected here to demonstrate the compatibility of the nanocomposite electrolyte with potential cathode materials because it is the most widely studied rechargeable $\mathrm{Mg}$ cathode material [77] even though its capacity is low. Higher performance is expected using higher capacity cathode materials.

\section{${ }^{25}$ Mg solid-state NMR}

The high performance of the $\mathrm{Mg}\left(\mathrm{BH}_{4}\right)_{2}-\mathrm{MgO}-\mathrm{PEO}$ nanocomposite polymer electrolyte inspired us to explore the mechanism for why this nanocomposite electrolyte exhibits excellent performance in contrast to many other solid polymer electrolytes. For example, we found that the 
corresponding $\mathrm{Mg}(\mathrm{TFSI})_{2}-\mathrm{MgO}-\mathrm{PEO}$ nanocomposite does not produce reversible $\mathrm{Mg}$ plating/stripping (Supplementary Figure S1). Hence, solid-state NMR measurements were conducted to understand the $\mathrm{Mg}$ chemical environment in the solid PEO matrix, i.e., the interaction between $\mathrm{Mg}$ ions and PEO. The ${ }^{25} \mathrm{Mg}$ solid-state NMR spectrum (Figure 3) obtained from pure $\operatorname{Mg}\left(\mathrm{BH}_{4}\right)_{2}$ shows a typical second order quadrupolar powder pattern from the central transition $(\mathrm{m}=+1 / 2 \leftrightarrow-1 / 2)$ of a quadrupolar nucleus ${ }^{25} \mathrm{Mg}$ with nuclear spin number $\mathrm{I}=5 / 2$ [78]. This characteristic second-order powder pattern disappears in $\mathrm{Mg}\left(\mathrm{BH}_{4}\right)_{2}-\mathrm{PEO}(\mathrm{MgO}$ is not included in the NMR study in order to facilitate the analysis) which indicates a strong interaction between the $\mathrm{Mg}^{2+}$ cations and the oxygen atoms in the PEO chains (the XRD powder pattern shows the loss of crystallinity of $\mathrm{Mg}\left(\mathrm{BH}_{4}\right)_{2}$ in the $\mathrm{Mg}\left(\mathrm{BH}_{4}\right)_{2}-\mathrm{PEO}$ polymer electrolyte, see Supplementary Figure S2). However, in contrast to the ${ }^{25} \mathrm{Mg}$ NMR spectra of the $\mathrm{Mg}(\mathrm{TFSI})_{2}-$ PEO polymer electrolyte (Figure S1), the ${ }^{25} \mathrm{Mg}$ spectrum of $\mathrm{Mg}\left(\mathrm{BH}_{4}\right)_{2}-\mathrm{PEO}$ does not show the resonance peaks at $26.7 \mathrm{ppm}$ or $-166.5 \mathrm{ppm}$ which indicates an absence of the hexagonal $\mathrm{Mg}-\mathrm{O}$ coordination $\left(\mathrm{MgO}_{6}\right)$ and its sideband [78] which are due to the coordination of the $\mathrm{Mg}^{2+}$ cations and the oxygen atoms from PEO, and also perhaps from some of the oxygen atoms of the $\mathrm{TFSI}^{-}$ anions (for the $\mathrm{Mg}(\mathrm{TFSI})_{2}-\mathrm{PEO}$ polymer electrolyte) [38]. However, it has been reported [79] that there are no ion pairs in $\mathrm{Mg}(\mathrm{TFSI})_{2}-\mathrm{PEO}$ electrolytes when the ratio between the repeating EO units $\left(-\mathrm{CH}_{2}-\mathrm{O}-\right)$ and $\mathrm{Mg}^{2+}$ cations is larger than 9 and the usual coordination number for $\mathrm{Mg}^{2+}$ cations is six. In our $\mathrm{Mg}(\mathrm{TFSI})_{2}-\mathrm{PEO}$ electrolyte, the EO/ $\mathrm{Mg}^{2+}$ ratio is 20 . In related LiXPEO polymer electrolytes with weakly coordinating anions such as TFSI, $\mathrm{Li}^{-} \mathrm{O}_{6}$ coordination by ether oxygens alone occurs if the $\mathrm{EO} / \mathrm{Li}^{+}$ratio is high enough [80-82]. Due to the similar cation size, $\mathrm{Mg}^{2+}-\mathrm{PEO}$ mixtures may have a comparable coordination environment to $\mathrm{Li}^{+}-\mathrm{PEO}$ mixtures. Therefore, the $\mathrm{Mg}^{2+}$ cations in $\mathrm{Mg}(\mathrm{TFSI})_{2} / \mathrm{PEO}$ may be strongly coordinated by six 
oxygen atoms and their mobility thus limited which perhaps explains, in part, why the $\mathrm{Mg}(\mathrm{TFSI})_{2}-\mathrm{PEO}$ electrolyte does not produce reversible $\mathrm{Mg}$ plating/stripping and its $\mathrm{Mg}^{2+}$ transport number is close to zero [61-63].

The ${ }^{25} \mathrm{Mg}$ NMR resonance obtained from the $\mathrm{Mg}\left(\mathrm{BH}_{4}\right)_{2}-\mathrm{PEO}$ electrolyte is rather broad at $25^{\circ} \mathrm{C}$, whereas that at higher temperature $\left(80^{\circ} \mathrm{C}\right)$ can be fitted to both narrow and broad components (Figure 3). The fast motion of the $\mathrm{Mg}^{2+}$ cations averages out anisotropic components that would otherwise appear in the ${ }^{25} \mathrm{Mg}$ spectrum, resulting in a narrower line width, via socalled motional narrowing [83]. This suggests that the amounts of fast moving $\mathrm{Mg}^{2+}$ cations, which corresponds to the relative peak area of the narrow component, is significantly enhanced with increasing temperature, likely due to the enhancement of chain fluctuations, which is similar to the enhancement of $\mathrm{Li}^{+}$cation mobility in polymer electrolytes with dissolved $\mathrm{LiX}$ salts $[84,85]$. The mobility enhancement of the $\mathrm{Mg}^{2+}$ cations at elevated temperature is also observed from the ${ }^{11} \mathrm{~B}$ and ${ }^{1} \mathrm{H}$ NMR spectrum (Supplementary Figure S3) where both the ${ }^{11} \mathrm{~B}$ and ${ }^{1} \mathrm{H}$ resonances become narrower in the $\mathrm{Mg}\left(\mathrm{BH}_{4}\right)_{2}-\mathrm{PEO}$ electrolyte. These results represent the first NMR study of solid-state electrolytes for rechargeable Mg battery applications.

\section{Discussion}

\section{Model system study}

In order to further understand how the coordination interactions affect the electrochemical properties, we chose smaller glyme model molecules (DME, diglyme, triglyme and tetraglyme) which have a similar structure to PEO. This makes the characterization and theoretical modeling easier since PEO is a large molecule without a well-defined molecular weight. 
Figure 4a shows the cyclic voltammograms $(\mathrm{CVs})$ of $\mathrm{Mg}$ plating/stripping in the four solutions: $\mathrm{Mg}\left(\mathrm{BH}_{4}\right)_{2}-\mathrm{DME}, \mathrm{Mg}\left(\mathrm{BH}_{4}\right)_{2}$-diglyme, $\mathrm{Mg}\left(\mathrm{BH}_{4}\right)_{2}$-triglyme and $\mathrm{Mg}\left(\mathrm{BH}_{4}\right)_{2}$-tetraglyme (0.01M Mg(BH $\left(\mathrm{BH}_{4}\right)_{2}$ was used due to the limited solubility of $\mathrm{Mg}\left(\mathrm{BH}_{4}\right)_{2}$ in glymes [39]). The $\mathrm{CE}$ for $\mathrm{Mg}$ plating/stripping is also shown. As is evident, the $\mathrm{CE}$ (and the current density) increases in the order of tetraglyme $>$ triglyme $>$ diglyme $>$ DME (i.e., the efficiency increases with increasing chain length of the glymes). Thus, we infer that longer chain glymes favor the electrochemical processes of Mg plating/stripping.

In the $\mathrm{Mg}\left(\mathrm{BH}_{4}\right)_{2}-$ glyme solutions, since the complete dissociation of $\mathrm{Mg}\left(\mathrm{BH}_{4}\right)_{2}$ is unlikely $[14,86]$, we propose the following simplified equilibrium to describe the dissociation of $\operatorname{Mg}\left(\mathrm{BH}_{4}\right)_{2}$ :

$$
\left[\mathrm{Mg}\left(\mathrm{BH}_{4}\right)_{2}\right] \leftrightarrow\left[\mathrm{Mg}\left(\mathrm{BH}_{4}\right)\right]^{+}+\mathrm{BH}_{4}^{-} \leftrightarrow[\mathrm{Mg}]^{2+}+2 \mathrm{BH}_{4}^{-}(1)
$$

with the overall $\mathrm{Mg}^{2+}$ coordination number to anions and/or ether oxygens likely to be constant at five-six. This dissociation equilibrium will be influenced by the solvent structure (in the case of glymes, they can be considered to be ligands) which provide a driving force for the salt dissociation. Stronger coordination between the $\mathrm{Mg}^{2+}$ cations and solvent will lead to a higher degree of dissociation of the $\mathrm{Mg}^{2+}$ cations and $\mathrm{BH}_{4}{ }^{-}$anions. For electrolytes with lithium salts, fully ion dissociation (i.e., full cation solvation) is desirable as this generally improves the electrochemical properties of the electrolyte as well-solvated charge carriers usually correlate with improved charge transfer-both in the bulk electrolyte and at the electrode interface. But, importantly, this may not be the case for $\mathrm{Mg}^{2+}$-based electrolytes, as exemplified by the poor performance of electrolytes with the weakly coordinating $\mathrm{TFSI}^{-}$anion. Full solvation (i.e., $[\mathrm{Mg}]^{2+}$ ) - by either one or two polyether chains—may result in immobilized $\mathrm{Mg}^{2+}$ cations due to the stronger coordinate bonds formed between the cations and ether oxygens than for $\mathrm{Li}^{+}$cations. 
Extensive ionic association (i.e., $\left[\mathrm{Mg}\left(\mathrm{BH}_{4}\right)_{2}\right]_{\mathrm{x}}$ aggregate clusters of cations and anions) is also undesirable as the mobility of the $\mathrm{Mg}^{2+}$ cations will again be strongly restricted. Instead, some form of intermediate association (i.e., $\left[\mathrm{Mg}\left(\mathrm{BH}_{4}\right)\right]^{+}$) in which the cations are only partially solvated by one or two polyether chains may lead to the most favorable mobility of the cations.

Glymes are considered to be very effective at coordinating cations due to both the strong donor character of the ether oxygen electron lone pairs and to the flexibility of the ethylene oxide segments [87]. Therefore, in the $\mathrm{Mg}\left(\mathrm{BH}_{4}\right)_{2}$-glyme mixtures, the coordination interactions between the $\mathrm{Mg}^{2+}$ cations and glymes originates from the coordination by the ether oxygens. Stronger interactions (i.e., increased electron donation) would increase the shielding of the $\mathrm{Mg}$ nuclei, thus lowering the ${ }^{25} \mathrm{Mg}$ NMR chemical shift. This is shown in ${ }^{25} \mathrm{Mg}$ NMR spectra of these solutions in Figure $4 \mathrm{~b}$. It is evident that the ${ }^{25} \mathrm{Mg}$ chemical shift moves to lower values from DME through diglyme to triglyme. This indicates that the coordination interactions increase with chain length, which is consistent with the known literature [88-91]. However, interestingly, the ${ }^{25} \mathrm{Mg}$ chemical shift in tetraglyme falls between that of triglyme and diglyme.

To aid in identifying the origin for the exception of tetraglyme from the length-dependent trend observed for the other species, DFT calculations were carried out. Based upon our previous report [39] and the coordination structures of $\mathrm{Mg}^{2+}$ cations with ethers and glymes [88, 92, 93], the $\operatorname{Mg}\left(\mathrm{BH}_{4}\right)_{2}$ coordination structures in different glymes were assigned to be: $\left[\mathrm{Mg}\left(\mathrm{BH}_{4}\right)_{2}\right]_{2} \cdot 3 \mathrm{DME}, \mathrm{Mg}\left(\mathrm{BH}_{4}\right)_{2} \cdot$ diglyme, $\mathrm{Mg}\left(\mathrm{BH}_{4}\right)_{2}$ ·triglyme, and $\mathrm{Mg}\left(\mathrm{BH}_{4}\right)_{2} \cdot$ tetraglyme. The DFT calculated ${ }^{25} \mathrm{Mg}$ NMR chemical shift trend was found to be (Supplementary Table S1):

$\left[\mathrm{Mg}\left(\mathrm{BH}_{4}\right)_{2}\right]_{2} \cdot 3 \mathrm{DME}>\mathrm{Mg}\left(\mathrm{BH}_{4}\right)_{2} \cdot$ diglyme $>\mathrm{Mg}\left(\mathrm{BH}_{4}\right)_{2} \cdot$ triglyme $>\mathrm{Mg}\left(\mathrm{BH}_{4}\right)_{2}$ ·tetraglyme If, however, one of the $\mathrm{BH}_{4}{ }^{-}$anions is removed from the $\mathrm{Mg}\left(\mathrm{BH}_{4}\right)_{2}$.tetraglyme complex (i.e., $\mathrm{Mg}\left(\mathrm{BH}_{4}\right)_{2}$ dissociates), the DFT calculated ${ }^{25} \mathrm{Mg}$ NMR chemical shift trend is instead: 
$\left[\mathrm{Mg}\left(\mathrm{BH}_{4}\right)_{2}\right]_{2} \cdot 3 \mathrm{DME}>\mathrm{Mg}\left(\mathrm{BH}_{4}\right)_{2} \cdot$ diglyme $>\left[\mathrm{Mg}\left(\mathrm{BH}_{4}\right)\right]^{+}$.tetraglyme $>\mathrm{Mg}\left(\mathrm{BH}_{4}\right)_{2} \cdot$ triglyme which is in excellent agreement with the trend shown in Figure 4b. This result indicates that higher $\mathrm{Mg}\left(\mathrm{BH}_{4}\right)_{2}$ dissociation may perhaps be expected in tetraglyme.

The ${ }^{25} \mathrm{Mg}$ NMR peak shapes is also informative regarding the dissociation of $\mathrm{Mg}\left(\mathrm{BH}_{4}\right)_{2}$ in the series of glymes. The line width-measured through the full-width-at-half-maximum $\left(\Delta v_{1 / 2}\right)$-increases from DME $(85 \mathrm{~Hz})$, diglyme $(128 \mathrm{~Hz})$, triglyme $(327.62 \mathrm{~Hz})$ to tetraglyme $(527.67 \mathrm{~Hz})$ (Figure 2), indicating the enhancement of diversity of the coordination environment surrounding the $\mathrm{Mg}^{2+}$ cations in long chain glymes. Based upon the above $\mathrm{Mg}\left(\mathrm{BH}_{4}\right)_{2}$ dissociation equilibrium (Eq. 1), we infer that the ${ }^{25} \mathrm{Mg}$ NMR peak is the overall averaged signal of solvated $\left[\mathrm{Mg}\left(\mathrm{BH}_{4}\right)_{2}\right],\left[\mathrm{Mg}\left(\mathrm{BH}_{4}\right)\right]^{+}$, and $[\mathrm{Mg}]^{2+}$ solvate species. The narrow peaks for DME and diglyme likely originate from these solvents forming complexes in which all of the solvent ether oxygens are coordinated to the $\mathrm{Mg}^{2+}$ cations. For example, this occurs in crystalline solvate structures for $(\mathrm{DME})_{2}: \mathrm{Ca}\left(\mathrm{BH}_{4}\right)_{2}$ and (diglyme $)_{1}: \operatorname{Mg}\left(\mathrm{BH}_{4}\right)_{2}[93,94]$. The longer triglyme and tetraglyme, with more ether oxygens and conformation flexibility, may instead adopt more numerous modes of coordination to the cations, with some or all of the ether oxygens from one or two glyme molecules coordinated, which may vary the local environment of the $\mathrm{Mg}^{2+}$ cations to a greater extent (for both the solvent and anion coordination due to steric factors) thus explaining the broad peak widths observed for the solutions with these glymes.

This is also confirmed from the transmittance FTIR spectra. The spectrum in the range of $2500-2100 \mathrm{~cm}^{-1}$ is shown in Figure 4c. A comparison of the B-H stretching from $\mathrm{Mg}\left(\mathrm{BH}_{4}\right)_{2}$ dissolved in DME, diglyme, triglyme and tetraglyme shows a vibration band around $2170 \mathrm{~cm}^{-1}$, which is not present in the pure solvents, which is assigned as the B-H stretching feature. The red-shift of the $\sim 2170 \mathrm{~cm}^{-1}$ peak is clearly evidenced by changing the solvent from DME to 
tetraglyme (Figure 4c), indicating the presence of more uncoordinated $\mathrm{BH}_{4}^{-}$anions in the solutions with longer chain glymes [14]. This is consistent with the NMR results showing that longer glymes promote the dissociation of $\mathrm{Mg}\left(\mathrm{BH}_{4}\right)_{2}$ to a greater extent. It should be noted that the vibration features from the solvent molecules (e.g., peaks at $\sim 2400,2350,2240,2130 \mathrm{~cm}^{-1}$ ) are even stronger than for the B-H stretching from $\mathrm{Mg}\left(\mathrm{BH}_{4}\right)_{2}$, and the very low concentration of $\mathrm{Mg}\left(\mathrm{BH}_{4}\right)_{2}$ due to its poor solubility further decreases the intensity of the B-H peaks.

\section{Molecular dynamics simulations}

Classical MD simulations of the electrolyte system were performed to obtain a better understanding of the effects of ligands on the ionic coordination in the glyme solutions. Figure 5a shows the obtained average radial distribution function (RDF) for the $\mathrm{Mg}^{2+}$ cation interaction with specific atoms in the anion and tetraglyme (similar RDFs are obtained for $\mathrm{Mg}\left(\mathrm{BH}_{4}\right)_{2}$ in DME, diglyme and triglyme). The first coordination shell originates from $\mathrm{Mg}-\mathrm{H}$ (from $\mathrm{BH}_{4}{ }^{-}$) and manifests around 1.9 $\AA$ followed by another strong peak from $\mathrm{Mg}-\mathrm{B}$ (from $\mathrm{BH}_{4}{ }^{-}$) at $2.3 \AA$, indicating a very strong and rigid interaction between the salt cation and anion and arguing for the formation of ion-pairs and/or aggregates in the liquid electrolytes. The peak for $\mathrm{Mg}-\mathrm{O}$ (from tetraglyme) is observed at $2.1 \AA$, while the $\mathrm{Mg}-\mathrm{C}$ (from tetraglyme) peak occurs at $3.1 \AA$, consistent with the solvent as a secondary ligand. These RDF results are consistent with the literature in that the coordination between the $\mathrm{Mg}^{2+}$ and $\mathrm{BH}_{4}{ }^{-}$ions is through the $\mathrm{Mg}-\mathrm{H}$ bond (instead of $\mathrm{Mg}-\mathrm{B}$ bond) [39] and between $\mathrm{Mg}^{2+}$ and the glymes through the $\mathrm{Mg}-\mathrm{O}$ bond $[39,87]$. Figure $5 \mathrm{~b}$ shows the RDF of $\mathrm{Mg}-\mathrm{O}$ (from glyme) for the different glymes, where we observe a shift in the peak position to a shorter distance with an increase in the chain length from DME to

tetraglyme which signifies the enhanced interaction between the $\mathrm{Mg}^{2+}$ cation and oxygens of glymes with the increase in chain length. Also, we find that the coordination numbers of $\mathrm{BH}_{4}{ }^{-}$in 
the first coordination shell of the $\mathrm{Mg}^{2+}$ cations falls quite dramatically from 1.969 in DME to 0.628 in tetraglyme, supporting the conclusions regarding a higher dissociative tendency (i.e., less ionic association) for the long-chain glymes (Supplementary Figure S5).

The above analysis implies that even higher dissociation of $\mathrm{Mg}\left(\mathrm{BH}_{4}\right)_{2}$ may be expected in PEO [88]; but due to the absence of the hexagonal $\mathrm{Mg}-\mathrm{O}$ coordination $\left(\mathrm{MgO}_{6}\right)$ in $\mathrm{Mg}\left(\mathrm{BH}_{4}\right)_{2}-$ PEO, the complete dissociation of $\mathrm{Mg}\left(\mathrm{BH}_{4}\right)_{2}$ is unlikely. Therefore, it is possible that many of the $\left[\mathrm{BH}_{4}\right]^{-}$anions are dissociated from the divalent $\mathrm{Mg}^{2+}$ cations resulting in solvated $\left[\mathrm{MgBH}_{4}\right]^{+}$ ion pairs; thus, the solvated $\left[\mathrm{MgBH}_{4}\right]^{+}$cation complexes may function as the main $\mathrm{Mg}^{2+}$ charge carrier in the nanocomposite polymer electrolytes. More experimental and theoretical simulation work is needed, however, to further delineate the solvation and ionic association interactions within such electrolytes.

\section{Conclusions}

In summary, a nanocomposite polymer electrolyte consisting of $\mathrm{PEO}, \mathrm{Mg}\left(\mathrm{BH}_{4}\right)_{2}$ and $\mathrm{MgO}$ nanoparticles has been developed for rechargeable $\mathrm{Mg}$ batteries. It results in a high coulombic efficiency of $98 \%$ for $\mathrm{Mg}$ plating/stripping, high cycling stability, and highly efficient $\mathrm{Mg}$ intercalation/de-intercalation in $\mathrm{Mo}_{6} \mathrm{~S}_{8} . \quad \mathrm{A}$ fundamental combined experiment-modeling investigation has been conducted to understand the mechanisms behind the enhanced performance. $\mathrm{Mg}\left(\mathrm{BH}_{4}\right)_{2}-$ glyme electrolytes have been utilized to aid in elucidating the effects of ligand structure on the electrochemical properties of $\mathrm{Mg}$ electrolytes. Longer-chain glymes demonstrate a stronger coordinating capability to the $\mathrm{Mg}^{2+}$ cations through their increased electron donor and chelating ability. An even more enhanced dissociation of the salt $\mathrm{Mg}\left(\mathrm{BH}_{4}\right)_{2}$ is thus expected in PEO and, if following the same trend as for the glymes, improved electrochemical performance. The reason that reversible $\mathrm{Mg}$ plating/stripping was observed in 
$\mathrm{Mg}\left(\mathrm{BH}_{4}\right)_{2}$ - $\mathrm{MgO}-\mathrm{PEO}$ nanocomposite polymer electrolytes but not in $\mathrm{Mg}(\mathrm{TFSI})_{2}-\mathrm{MgO}-\mathrm{PEO}$ is probably that it forms solvated $\left[\mathrm{MgBH}_{4}\right]^{+}$cation complexes in the former. The understanding and design metrics obtained from the $\mathrm{Mg}\left(\mathrm{BH}_{4}\right)_{2} / \mathrm{PEO}$ nanocomposite system may be further developed and utilized in nanocomposite solid electrolytes for other multivalent chemistry.

\section{Acknowledgments}

This work was primarily supported as part of the Joint Center for Energy Storage Research (JCESR), an Energy Innovation Hub funded by the U.S. Department of Energy (DOE), Office of Science, Basic Energy Sciences under Contract No. DE-AC02-06CH11357. The materials characterizations (NMR, IR, SEM, XRD, etc.) were conducted in the William R. Wiley Environmental Molecular Sciences Laboratory (EMSL), a national scientific user facility sponsored by DOE's Office of Biological and Environmental Research and located at Pacific Northwest National Laboratory (PNNL). PNNL is operated by Battelle for the DOE under Contract DE-AC05-76RLO1830. This research used resources of the National Energy Research Scientific Computing Center, which is supported by the Office of Science of the U.S. Department of Energy under Contract No. DE-AC02-05CH11231.

\section{Appendix B. Author contribution}

Y.Y. Shao and J. Liu conceived and designed this work. Y.Y. Shao conducted the electrochemistry work; J.Z. Hu, T.B. Liu, M.Y. Hu, X.C. Deng, and S.C. Xu acquired the NMR data; Y.Y. Shao, J.Z. Hu, T.B. Liu, K.S. Han, and K. T. Mueller analyzed the NMR data; Z.H. Wei and Y. Wang acquired and analyzed the IR data; Y.Y. Shao and J.L. Wang fabricated and tested the nanocomposite electrolytes; M. Gu and C.M. Wang carried out the electron microscopy characterization; Z.M. Nie acquired and analyzed the XRD data; G.S. Li provided 
the cathode material; N. N. Rajput and K. Persson performed the MD simulations; Y.Y. Shao, N. N. Rajput, K. Persson and J. Liu wrote the paper; K.R. Zavadil, W.A. Henderson and T.B. Liu contributed significantly to the preparation of the manuscript. All authors participated in the discussion of the work.

\section{REFERENCES:}

[1] D. Aurbach, Z. Lu, A. Schechter, Y. Gofer, H. Gizbar, R. Turgeman, Y. Cohen, M. Moshkovich, E. Levi, Nature, 407 (2000) 724-727.

[2] H.D. Yoo, I. Shterenberg, Y. Gofer, G. Gershinsky, N. Pour, D. Aurbach, Energy Environ. Sci., 6 (2013) 2265-2279.

[3] M. Matsui, J. Power Sources, 196 (2011) 7048-7055.

[4] C. Ling, D. Banerjee, M. Matsui, Electrochim. Acta, 76 (2012) 270-274.

[5] O. Mizrahi, N. Amir, E. Pollak, O. Chusid, V. Marks, H. Gottlieb, L. Larush, E. Zinigrad, D. Aurbach, J. Electrochem. Soc., 155 (2008) A103-A109.

[6] D. Aurbach, E. Zinigrad, H. Teller, P. Dan, J. Electrochem. Soc., 147 (2000) 1274-1279.

[7] D. Aurbach, E. Zinigrad, Y. Cohen, H. Teller, Solid State Ion., 148 (2002) 405-416.

[8] F. Ding, W. Xu, G.L. Graff, J. Zhang, M.L. Sushko, X.L. Chen, Y.Y. Shao, M.H. Engelhard, Z.M. Nie, J. Xiao, X.J. Liu, P.V. Sushko, J. Liu, J.G. Zhang, J. Am. Chem. Soc., 135 (2013) 4450-4456.

[9] C. Liao, B.K. Guo, D.E. Jiang, R. Custelcean, S.M. Mahurin, X.G. Sun, S. Dai, J. Mater. Chem. A, 2 (2014) 581-584.

[10] D. Aurbach, G.S. Suresh, E. Levi, A. Mitelman, O. Mizrahi, O. Chusid, M. Brunelli, Adv. Mater., 19 (2007) 4260-4267.

[11] N. Pour, Y. Gofer, D.T. Major, D. Aurbach, J. Am. Chem. Soc., 133 (2011) 6270-6278.

[12] Y.S. Guo, F. Zhang, J. Yang, F.F. Wang, Y.N. NuLi, S.I. Hirano, Energy Environ. Sci., 5 (2012) $9100-$ 9106.

[13] H.S. Kim, T.S. Arthur, G.D. Allred, J. Zajicek, J.G. Newman, A.E. Rodnyansky, A.G. Oliver, W.C. Boggess, J. Muldoon, Nat. Commun., 2 (2011) doi: 10.1038/ncomms1435.

[14] R. Mohtadi, M. Matsui, T.S. Arthur, S.J. Hwang, Angew. Chem.-Int. Edit., 51 (2012) 9780-9783.

[15] E. Levi, G. Gershinsky, D. Aurbach, O. Isnard, G. Ceder, Chem. Mat., 21 (2009) 1390-1399.

[16] Y.P. Zheng, Y.N. NuLi, Q. Chen, Y. Wang, J. Yang, J.L. Wang, Electrochim. Acta, 66 (2012) 75-81.

[17] Y.N. Nuli, J. Yang, Y.S. Li, J.L. Wang, Chem. Commun., 46 (2010) 3794-3796.

[18] M. Inamoto, H. Kurihara, T. Yajima, Electrochemistry, 80 (2012) 421-422.

[19] E. Lancry, E. Levi, A. Mitelman, S. Malovany, D. Aurbach, J. Solid State Chem., 179 (2006) 18791882.

[20] Y.N. NuLi, Y.P. Zheng, Y. Wang, J. Yang, J.L. Wang, J. Mater. Chem., 21 (2011) 12437-12443.

[21] J. Muldoon, C.B. Bucur, A.G. Oliver, T. Sugimoto, M. Matsui, H.S. Kim, G.D. Allred, J. Zajicek, Y. Kotani, Energy Environ. Sci., 5 (2012) 5941-5950.

[22] D.P. Lv, D.H. Tang, Y.H. Duan, M.L. Gordin, F. Dai, P.Y. Zhu, J.X. Song, A. Manivannan, D.H. Wang, J. Mater. Chem. A, 2 (2014) 15488-15494.

[23] K. Xu, Chem. Rev., 104 (2004) 4303-4417. 
[24] D. Aurbach, Y. Gofer, Z. Lu, A. Schechter, O. Chusid, H. Gizbar, Y. Cohen, V. Ashkenazi, M. Moshkovich, R. Turgeman, E. Levi, J. Power Sources, 97-98 (2001) 28-32.

[25] D. Aurbach, Y. Gofer, A. Schechter, O. Chusid, H. Gizbar, Y. Cohen, M. Moshkovich, R. Turgeman, J. Power Sources, 97-8 (2001) 269-273.

[26] T.D. Gregory, R.J. Hoffman, R.C. Winterton, J. Electrochem. Soc., 137 (1990) 775-780.

[27] D. Aurbach, A. Schechter, M. Moshkovich, Y. Cohen, J. Electrochem. Soc., 148 (2001) A1004-

A1014.

[28] N. Amir, Y. Vestfrid, O. Chusid, Y. Gofer, D. Aurbach, J. Power Sources, 174 (2007) 1234-1240.

[29] D. Aurbach, Y. Cohen, M. Moshkovich, Electrochem. Solid State Lett., 4 (2001) A113-A116.

[30] Z. Lu, A. Schechter, M. Moshkovich, D. Aurbach, J. Electroanal. Chem., 466 (1999) 203-217.

[31] D. Aurbach, I. Weissman, Y. Gofer, E. Levi, Chem. Rec., 3 (2003) 61-73.

[32] K. Xu, A. von Cresce, J. Mater. Chem., 21 (2011) 9849-9864.

[33] Y. Vestfried, O. Chusid, Y. Goffer, P. Aped, D. Aurbach, Organometallics, 26 (2007) 3130-3137.

[34] P. Saha, M.K. Datta, O.I. Velikokhatnyi, A. Manivannan, D. Alman, P.N. Kumta, Progress in Materials Science, 66 (2014) 1-86.

[35] I. Shterenberg, M. Salama, Y. Gofer, E. Levi, D. Aurbach, MRS Bull., 39 (2014) 453-460.

[36] D.P. Lv, T. Xu, P. Saha, M.K. Datta, M.L. Gordin, A. Manivannan, P.N. Kumta, D.H. Wang, J. Electrochem. Soc., 160 (2013) A351-A355.

[37] A. Kitada, Y. Kang, Y. Uchimoto, K. Murase, J. Electrochem. Soc., 161 (2014) D102-D106.

[38] G.A. Giffin, A. Moretti, S. Jeong, S. Passerini, J. Phys. Chem. C, 118 (2014) 9966-9973.

[39] Y. Shao, T. Liu, G. Li, M. Gu, Z. Nie, M. Engelhard, J. Xiao, D. Lv, C. Wang, J.-G. Zhang, J. Liu, Sci Rep, 3 (2013).

[40] S. Higashi, K. Miwa, M. Aoki, K. Takechi, Chem. Commun., 50 (2013) 1320-1322.

[41] S.Y. Ha, Y.W. Lee, S.W. Woo, B. Koo, J.S. Kim, J. Cho, K.T. Lee, N.S. Choi, ACS Appl. Mater. Interfaces, 6 (2014) 4063-4073.

[42] Y.N. NuLi, J. Yang, R. Wu, Electrochem. Commun., 7 (2005) 1105-1110.

[43] Y. NuLi, J. Yang, J.L. Wang, J.Q. Xu, P. Wang, Electrochem. Solid State Lett., 8 (2005) C166-C169.

[44] T. Kakibe, N. Yoshimoto, M. Egashira, M. Morita, Electrochem. Commun., 12 (2010) 1630-1633.

[45] Y. Kumar, S.A. Hashmi, G.P. Pandey, Electrochim. Acta, 56 (2011) 3864-3873.

[46] N.S.V. Narayanan, B.V.A. Raj, S. Sampath, Electrochem. Commun., 11 (2009) 2027-2031.

[47] W.H. Meyer, Adv. Mater., 10 (1998) 439-+.

[48] A.M. Christie, S.J. Lilley, E. Staunton, Y.G. Andreev, P.G. Bruce, Nature, 433 (2005) 50-53.

[49] F. Croce, G.B. Appetecchi, L. Persi, B. Scrosati, Nature, 394 (1998) 456-458.

[50] O. Chusid, Y. Gofer, H. Gizbar, Y. Vestfrid, E. Levi, D. Aurbach, I. Riech, Adv. Mater., 15 (2003) 627-630.

[51] M.L. Aubrey, R. Ameloot, B.M. Wiers, J.R. Long, Energy Environ. Sci., 7 (2014) 667-671.

[52] G.G. Kumar, N. Munichandraiah, Electrochim. Acta, 44 (1999) 2663-2666.

[53] G.G. Kumar, N. Munichandraiah, Electrochim. Acta, 47 (2002) 1013-1022.

[54] G.G. Kumar, N. Munichandraiah, J. Power Sources, 102 (2001) 46-54.

[55] M. Morita, N. Yoshimoto, S. Yakushiji, M. Ishikawa, Electrochem. Solid State Lett., 4 (2001) A177A179.

[56] M. Sundar, S. Selladurai, lonics, 12 (2006) 281-286.

[57] A.R. Polu, R. Kumar, K.V. Kumar, N.K. Jyothi, Effect of TiO2 Ceramic Filler on PEG-Based Composite Polymer Electrolytes for Magnesium Batteries, in: A.K. Chauhan, C. Murli, S.C. Gadkari (Eds.) Solid State Physics, Vol 57, Amer Inst Physics, Melville, 2013, pp. 996-997.

[58] V. Aravindan, G. Karthikaselvi, P. Vickraman, S.P. Naganandhini, J. Appl. Polym. Sci., 112 (2009) 3024-3029.

[59] N. Yoshimoto, S. Yakushiji, M. Ishikawa, M. Morita, Electrochim. Acta, 48 (2003) 2317-2322. 
[60] E. Quartarone, P. Mustarelli, Chem. Soc. Rev., 40 (2011) 2525-2540.

[61] L.L. Yang, A.R. McGhie, G.C. Farrington, J. Electrochem. Soc., 133 (1986) 1380-1385.

[62] R. Huq, G.C. Farrington, Solid State lon., 28 (1988) 990-993.

[63] C. Liebenow, A. Reiche, P. Lobitz, Electrochim. Acta, 40 (1995) 2375-2378.

[64] M. Saito, H. Ikuta, Y. Uchimoto, M. Wakihara, S. Yokoyama, T. Yabe, M. Yamamoto, J.

Electrochem. Soc., 150 (2003) A477-A483.

[65] M. Saito, H. Ikuta, Y. Uchimoto, M. Wakihara, S. Yokoyama, T. Yabe, M. Yamamoto, J. Phys. Chem. B, 107 (2003) 11608-11614.

[66] G.B. Appetecchi, F. Croce, J. Hassoun, B. Scrosati, M. Salomon, F. Cassel, J. Power Sources, 114 (2003) 105-112.

[67] F. Capuano, F. Croce, B. Scrosati, J. Electrochem. Soc., 138 (1991) 1918-1922.

[68] F. Croce, R. Curini, A. Martinelli, L. Persi, F. Ronci, B. Scrosati, R. Caminiti, J. Phys. Chem. B, 103 (1999) 10632-10638.

[69] C.T. Lee, W.T. Yang, R.G. Parr, Phys. Rev. B, 37 (1988) 785-789.

[70] A.D. Becke, Phys. Rev. A, 38 (1988) 3098-3100.

[71] S. Grimme, J. Antony, T. Schwabe, C. Muck-Lichtenfeld, Org. Biomol. Chem., 5 (2007) 741-758.

[72] E. Van Lenthe, E.J. Baerends, J. Comput. Chem., 24 (2003) 1142-1156.

[73] S. Pronk, S. Páll, R. Schulz, P. Larsson, P. Bjelkmar, R. Apostolov, M.R. Shirts, J.C. Smith, P.M. Kasson, D. van der Spoel, Bioinformatics, 29 (2013) 845-854.

[74] L. Martínez, R. Andrade, E.G. Birgin, J.M. Martínez, Journal of computational chemistry, 30 (2009) 2157-2164.

[75] W.L. Jorgensen, Yale University: New Haven, CT, (1997).

[76] J. Wang, R.M. Wolf, J.W. Caldwell, P.A. Kollman, D.A. Case, Journal of computational chemistry, 25 (2004) 1157-1174.

[77] E. Levi, Y. Gofer, D. Aurbach, Chem. Mat., 22 (2010) 860-868.

[78] P.J. Pallister, I.L. Moudrakovski, J.A. Ripmeester, Phys. Chem. Chem. Phys., 11 (2009) 1148711500.

[79] A. Bakker, S. Gejji, J. Lindgren, K. Hermansson, M.M. Probst, Polymer, 36 (1995) 4371-4378.

[80] W.A. Henderson, J. Phys. Chem. B, 110 (2006) 13177-13183.

[81] W.A. Henderson, S. Passerini, Electrochem. Commun., 5 (2003) 575-578.

[82] W.A. Henderson, Macromolecules, 40 (2007) 4963-4971.

[83] D.K. Yang, D.B. Zax, J. Chem. Phys., 110 (1999) 5325-5336.

[84] K. Hayamizu, E. Akiba, T. Bando, Y. Aihara, W.S. Price, Macromolecules, 36 (2003) 2785-2792.

[85] K.P. Barteau, M. Wolffs, N.A. Lynd, G.H. Fredrickson, E.J. Krarner, C.J. Hawker, Macromolecules, 46 (2013) 8988-8994.

[86] A.E. Shirk, D.F. Shriver, J. Am. Chem. Soc., 95 (1973) 5901-5904.

[87] W.A. Henderson, N.R. Brooks, Inorg. Chem., 42 (2003) 4522-4524.

[88] N.S. Poonia, A.V. Bajaj, Chem. Rev., 79 (1979) 389-445.

[89] M. Bremer, G. Linti, H. Noth, M. Thomann-Albach, G. Wagner, Z. Anorg. Allg. Chem., 631 (2005) 683-697.

[90] N. Vantruong, A.R. Norris, H.S. Shin, E. Buncel, R.A.B. Bannard, J.G. Purdon, Inorg. Chim. Acta, 184 (1991) 59-65.

[91] L.L. Chan, K.H. Wong, J. Smid, J. Am. Chem. Soc., 92 (1970) 1955-1963.

[92] E.B. Lobkovskii, L.V. Titov, S.B. Psikha, M.Y. Antipin, Y.T. Struchkov, J. Struct. Chem., 23 (1982) 644-646.

[93] E.B. Lobkovskii, L.V. Titov, M.D. Levicheva, A.N. Chekhlov, J. Struct. Chem., 31 (1990) 506-508.

[94] E. Hanecker, J. Moll, H. Noth, Z.Naturforsch.(B), 39 (1984) 424-430. 
Fig. 1 SEM images of the $\mathrm{Mg}\left(\mathrm{BH}_{4}\right)_{2}-\mathrm{MgO}-\mathrm{PEO}$ nanocomposite electrolyte. a, b) Surface top view images. c, d) Cross sectional images. e-h) Element mapping of the $\mathrm{Mg}\left(\mathrm{BH}_{4}\right)_{2}-\mathrm{MgO}-\mathrm{PEO}$ solid-state electrolyte.

Fig. 2 Electrochemical performance of the nanocomposite electrolyte $\mathrm{Mg}\left(\mathrm{BH}_{4}\right)_{2}-\mathrm{MgO}-\mathrm{PEO}$. a) $\mathrm{CV}\left(20 \mathrm{mV} \mathrm{s}^{-1}\right)$ of Mg plating/stripping on a stainless steel (ss) electrode. b) $\mathrm{CV}\left(0.05 \mathrm{~m} \mathrm{~V} \mathrm{~s}^{-1}\right)$ of $\mathrm{Mg}$ intercalation/deintercalation in $\mathrm{Mo}_{6} \mathrm{~S}_{8}$. c) Discharge/charge curve. d) Cycling stability of a solid-state $\mathrm{Mg}$ cell. All electrochemical tests were done in coin cells at $100{ }^{\circ} \mathrm{C}$. Cell architecture: a) $\mathrm{ss} / \mathrm{Mg}\left(\mathrm{BH}_{4}\right)_{2}-\mathrm{MgO}-\mathrm{PEO} / \mathrm{Mg}$, b, c, d) $\mathrm{Mo}_{6} \mathrm{~S}_{8} / \mathrm{Mg}\left(\mathrm{BH}_{4}\right)_{2}-\mathrm{MgO}-\mathrm{PEO} / \mathrm{Mg}$.

Fig. $3{ }^{25} \mathrm{Mg}$ solid-state NMR spectra of $\mathrm{Mg}\left(\mathrm{BH}_{4}\right)_{2}$ at $25^{\circ} \mathrm{C}$ and $\mathrm{Mg}\left(\mathrm{BH}_{4}\right)_{2}-\mathrm{PEO}$ at $25^{\circ} \mathrm{C}$ and $80{ }^{\circ} \mathrm{C}$.

Fig. 4 a) Cyclic voltammograms $\left(20 \mathrm{mV} \mathrm{s}^{-1}\right)$ on a Pt electrode in glymes containing $0.01 \mathrm{M}$ $\mathrm{Mg}\left(\mathrm{BH}_{4}\right)_{2}$. b) ${ }^{25} \mathrm{Mg}$ NMR spectra of $\mathrm{Mg}\left(\mathrm{BH}_{4}\right)_{2}$ in glymes solutions. c) FTIR spectra of $\mathrm{Mg}\left(\mathrm{BH}_{4}\right)_{2}$ dissolved in DME, diglyme, triglyme and tetraglyme.

Fig. 5 Molecular dynamics simulation results of $\mathrm{Mg}\left(\mathrm{BH}_{4}\right)_{2}-$ glyme systems. a) $\mathrm{RDF}$ of $\mathrm{Mg}\left(\mathrm{BH}_{4}\right)_{2}$ in tetraglyme. b) $\mathrm{RDF}$ of $\mathrm{Mg}-\mathrm{O}$ of $\mathrm{Mg}\left(\mathrm{BH}_{4}\right)_{2}$ in $\mathrm{DME}$, diglyme, triglyme and tetraglyme. c) Coordination numbers $(\mathrm{CN})$ of $\mathrm{Mg}$ with $\mathrm{B}$ (i.e., $\left.\mathrm{BH}_{4}\right)$. 


\section{FIGURES}
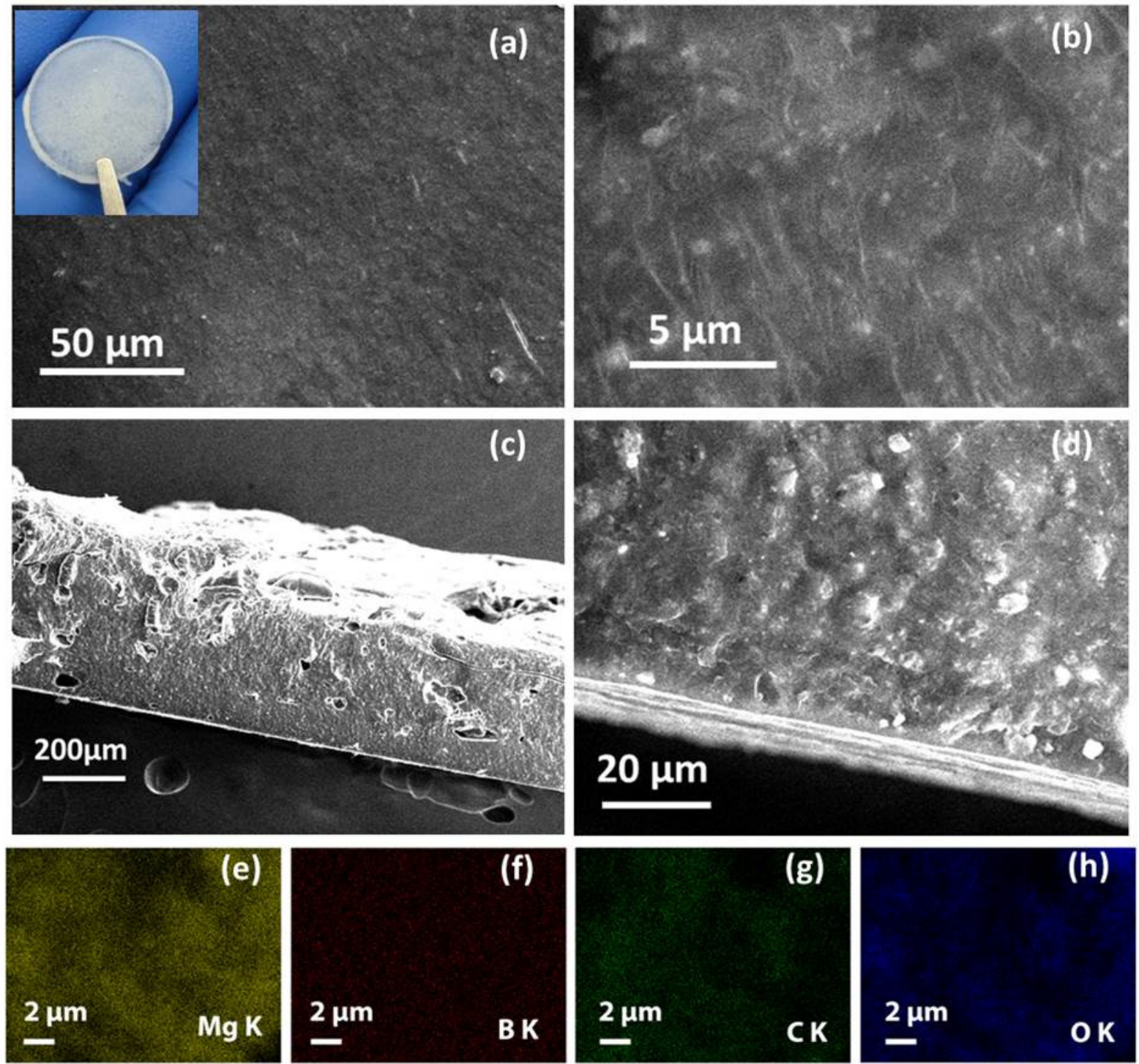

Fig. 1 SEM images of the $\mathrm{Mg}\left(\mathrm{BH}_{4}\right)_{2}-\mathrm{MgO}-\mathrm{PEO}$ nanocomposite electrolyte. a, b) Surface top view images. c, d) Cross sectional images. e-h) Element mapping of the $\mathrm{Mg}\left(\mathrm{BH}_{4}\right)_{2}-\mathrm{MgO}-\mathrm{PEO}$ nanocomposite electrolyte. 

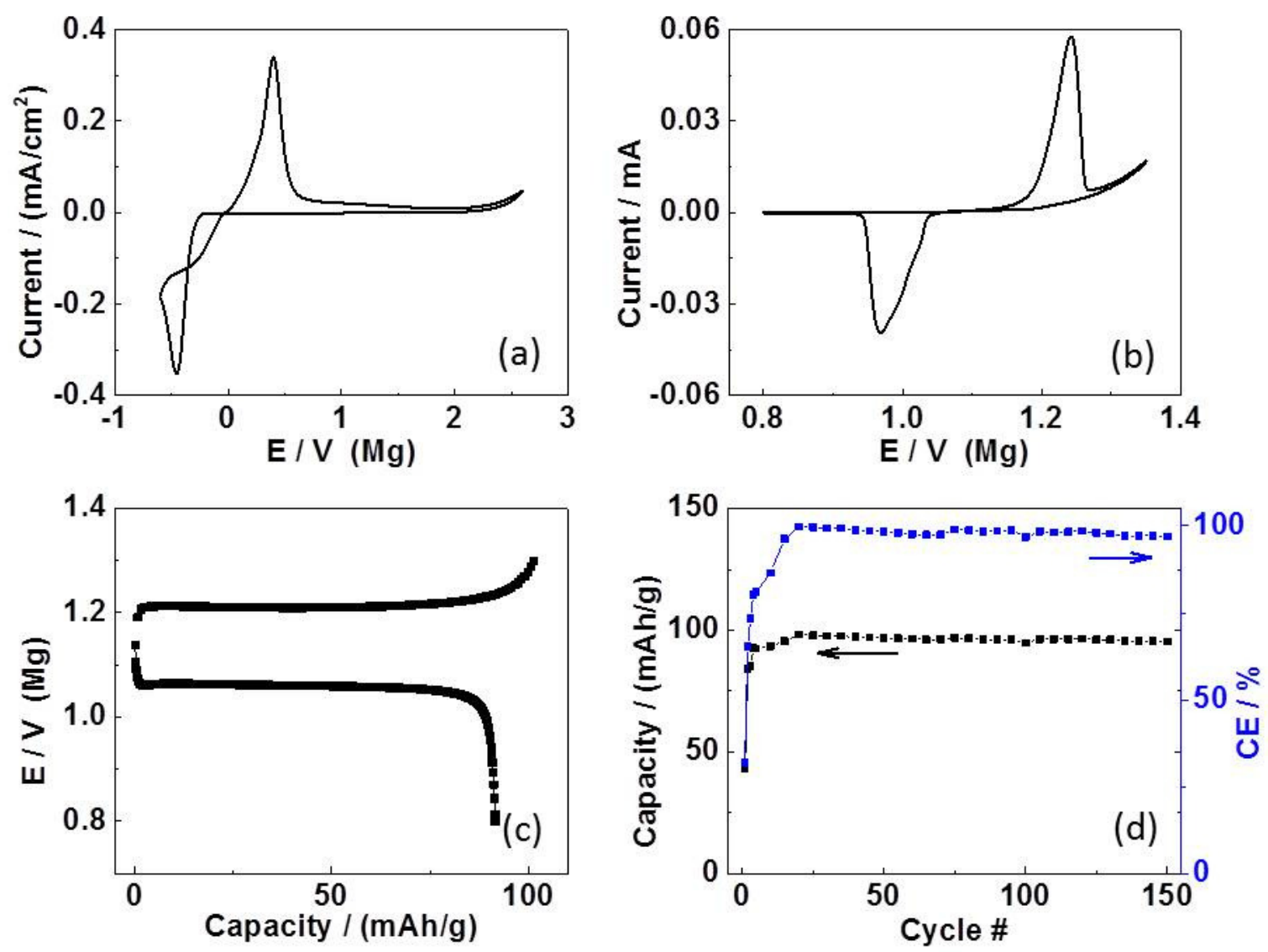

Fig. 2 Electrochemical performance of the nanocomposite electrolyte $\mathrm{Mg}\left(\mathrm{BH}_{4}\right)_{2}-\mathrm{MgO}-\mathrm{PEO}$. a) $\mathrm{CV}\left(20 \mathrm{mV} \mathrm{s}^{-1}\right)$ of $\mathrm{Mg}$ plating/stripping on a stainless steel (ss) electrode. b) $\mathrm{CV}\left(0.05 \mathrm{~m} \mathrm{~V} \mathrm{~s}^{-1}\right)$ of $\mathrm{Mg}$ intercalation/deintercalation in $\mathrm{Mo}_{6} \mathrm{~S}_{8}$. c) Discharge/charge curve. d) Cycling stability of a solid-state Mg cell. All electrochemical tests were done in coin cells at $100{ }^{\circ} \mathrm{C}$. Cell architecture: a) ss/Mg(BH4 $)_{2}-\mathrm{MgO}-\mathrm{PEO} / \mathrm{Mg}, \mathrm{b}, \mathrm{c}$, d) $\mathrm{Mo}_{6} \mathrm{~S}_{8} / \mathrm{Mg}\left(\mathrm{BH}_{4}\right)_{2}-\mathrm{MgO}-\mathrm{PEO} / \mathrm{Mg}$. 


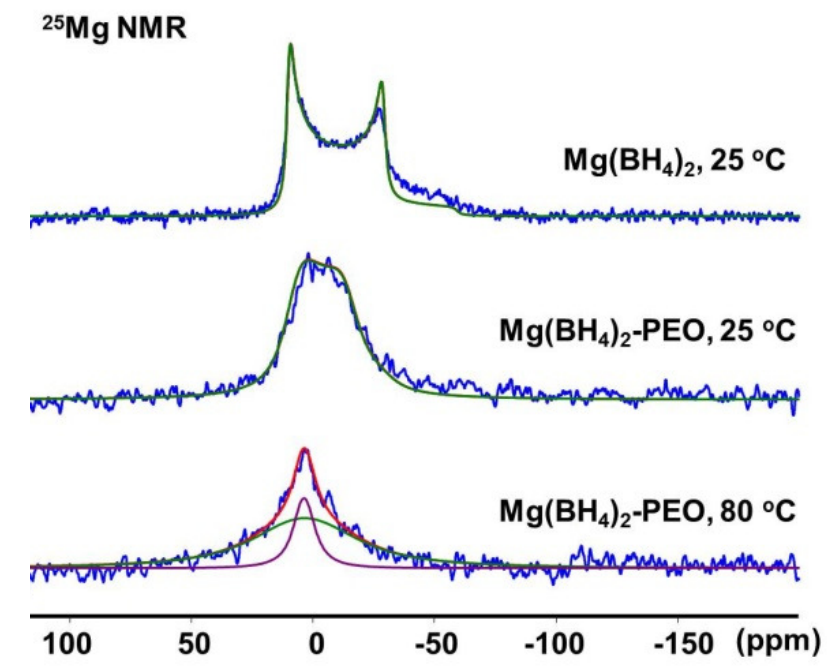

Fig. $3{ }^{25} \mathrm{Mg}$ solid-state $\mathrm{NMR}$ spectra of $\mathrm{Mg}\left(\mathrm{BH}_{4}\right)_{2}$ at $25^{\circ} \mathrm{C}$ and $\mathrm{Mg}\left(\mathrm{BH}_{4}\right)_{2}-\mathrm{PEO}$ at $25^{\circ} \mathrm{C}$ and $80{ }^{\circ} \mathrm{C}$. 

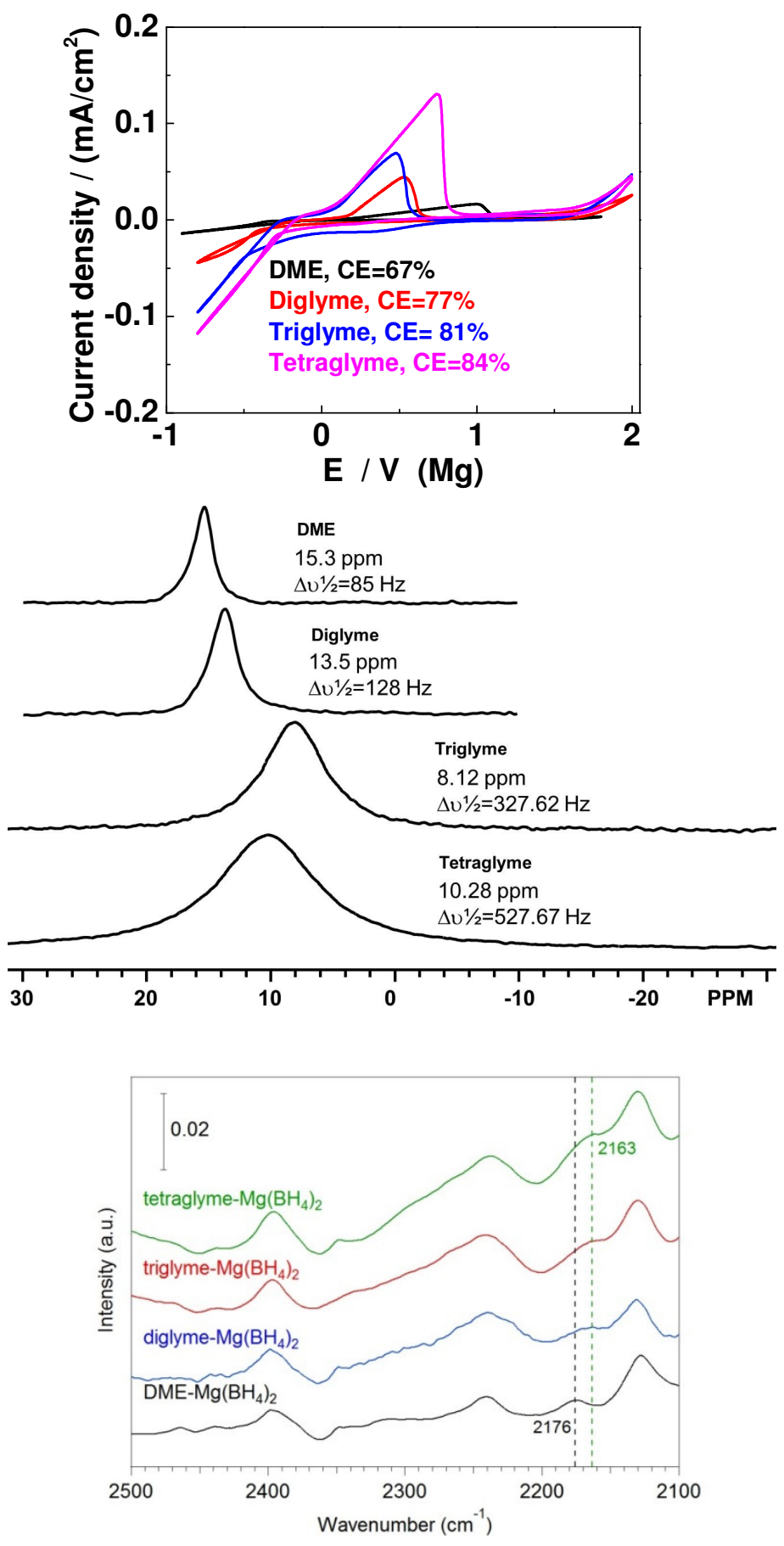

Fig. 4 a) Cyclic voltammograms $\left(20 \mathrm{mV} \mathrm{s}^{-1}\right)$ on a Pt electrode in glymes containing $0.01 \mathrm{M}$ $\mathrm{Mg}\left(\mathrm{BH}_{4}\right)_{2}$. b) ${ }^{25} \mathrm{Mg}$ NMR spectra of $\mathrm{Mg}\left(\mathrm{BH}_{4}\right)_{2}$ in glymes solutions. c) FTIR spectra of $\mathrm{Mg}\left(\mathrm{BH}_{4}\right)_{2}$ dissolved in DME, diglyme, triglyme and tetraglyme. 
a)

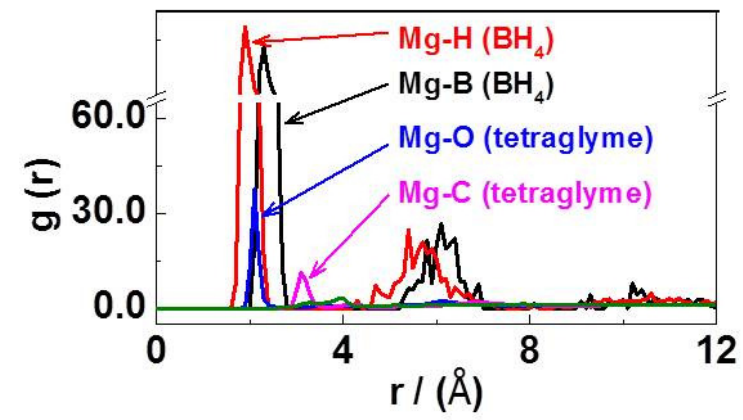

c)

\begin{tabular}{|l|l|l|l|l|} 
& DME & diglyme & triglyme & tetraglyme \\
\hline $\mathrm{CN}(\mathrm{Mg}-\mathrm{B})$ & 1.969 & 1.554 & 0.898 & 0.628 \\
\hline
\end{tabular}

Fig. 5 Molecular dynamics simulation results of $\mathrm{Mg}\left(\mathrm{BH}_{4}\right)_{2}-$ glyme systems. a) $\mathrm{RDF}$ of $\mathrm{Mg}\left(\mathrm{BH}_{4}\right)_{2}$ in tetraglyme. b) $\mathrm{RDF}$ of $\mathrm{Mg}-\mathrm{O}$ of $\mathrm{Mg}\left(\mathrm{BH}_{4}\right)_{2}$ in DME, diglyme, triglyme and tetraglyme. c) Coordination numbers $(\mathrm{CN})$ of $\mathrm{Mg}$ with $\mathrm{B}$ (i.e., $\mathrm{BH}_{4}{ }^{-}$). 


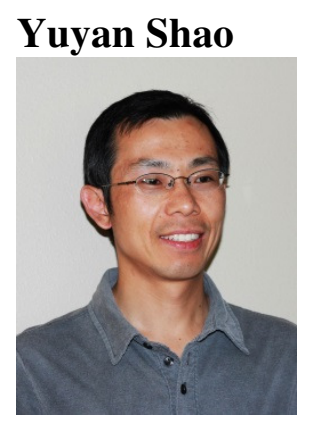

Yuyan Shao received his Ph.D. from Harbin Institute of Technology. He is a Senior Scientist in the Energy Processes and Materials Division of the Pacific Northwest National Laboratory. His research is focused on the fundamental study and high-performance functional materials for electrochemical energy conversion and storage, including fuel cells, batteries, supercapacitors, etc. He is named in Thomson Reuters' Highly Cited Researchers-2014. He has published over 80 papers.

\section{Nav Nidhi Rajput}

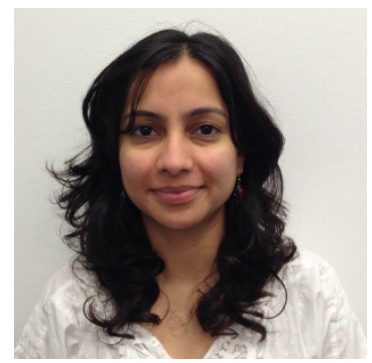

Nav Nidhi Rajput obtained her Ph.D. in Chemical Engineering at Louisiana State University in Louisiana, USA in 2013. She joined LBNL as a Postdoctoral Fellow at environmental energy technology division in 2013. Her research interests include molecular dynamics simulations to accelerate discovery of novel electrolytes for batteries and supercapacitors.

\section{Jianzhi Hu}

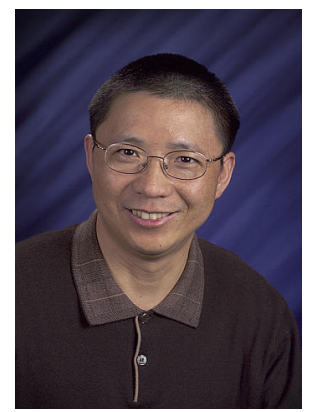

Jian Zhi Hu obtained his Ph.D. in Applied Physics in 1994 from a JointTraining Program between Wuhan Institute of Physics, the Chinese Academy of Sciences and the Department of Chemistry, University of Utah, USA. He did his postdoctoral studies also from University of Utah. Currently, he is a senior staff scientist of Pacific Norwest National Laboratory, specialized in nuclear magnetic resonance (NMR) spectroscopy and imaging. He has published more than 160 peer reviewed papers related to NMR. He is a holder of 8 issued US patents and a team member for a R\&D 100 award.

\section{Kristin Aslaug Persson}

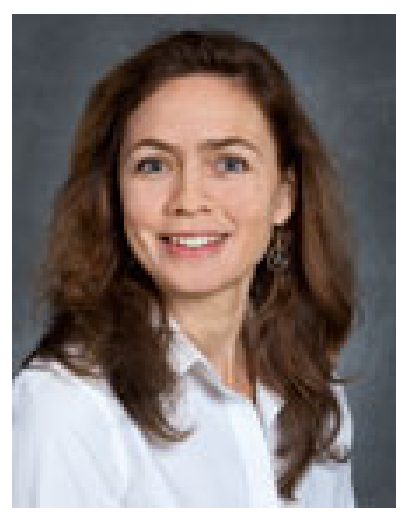

Kristin Aslaug Persson obtained her Ph.D. in Theoretical Physics at the Royal Institute of Technology in Stockholm, Sweden in 2001. She joined LBNL as a Staff Scientist in 2008 where she leads The Materials Project (www.materialsproject.org) and the Cross-Cutting thrust in the Joint Center for Energy Storage Research (JCESR) (www.jcesr.org). In 2009 she co-founded the clean-energy start-up Pellion Technologies Inc. (www.pelliontech.com), recipient of an ARPA-E award in 2010 for developing high-energy rechargeable magnesium batteries. 


\section{Jun Liu}

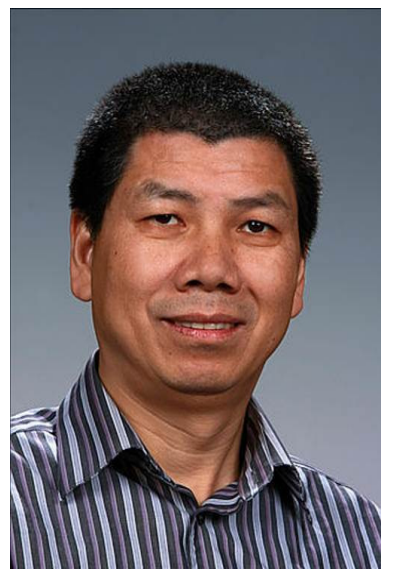

Jun Liu received his Ph.D. in materials science from University of Washington. He is a Laboratory Fellow and Energy Processes and Materials Division Director at the Pacific Northwest National Laboratory. Dr. Liu's main research interest includes synthesis of functional nanomaterials for energy storage, catalysis, environmental separation and health care. He has received more than 40 U.S. patents, two R\&D 100 Awards, two BES Awards for Significant Impact on DOE Missions, and was named 2007 Distinguished Inventor of Battelle. Dr. Liu is an AAAS Fellow and MRS Fellow. He is named in Thomson Reuters' Highly Cited Researchers-2014 in three categories (Materials science, Chemistry and Engineering). He has over 300 publications. 


\section{Graphical abstract:}

Nanocomposite polymer electrolyte for rechargeable magnesium batteries

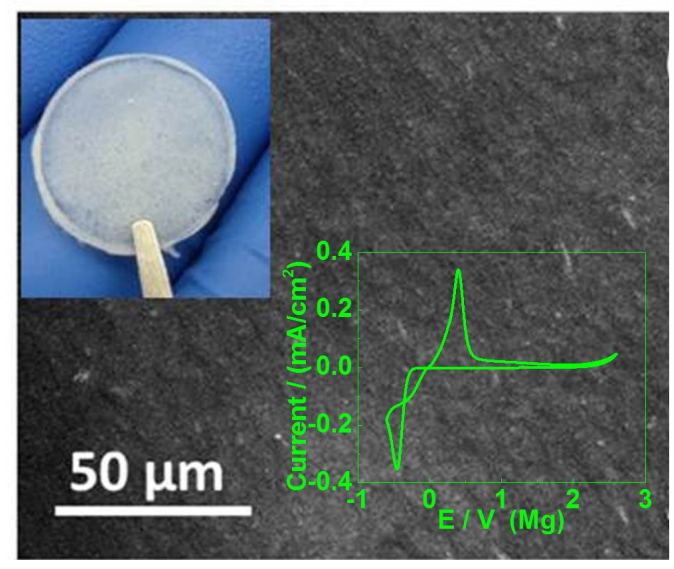

